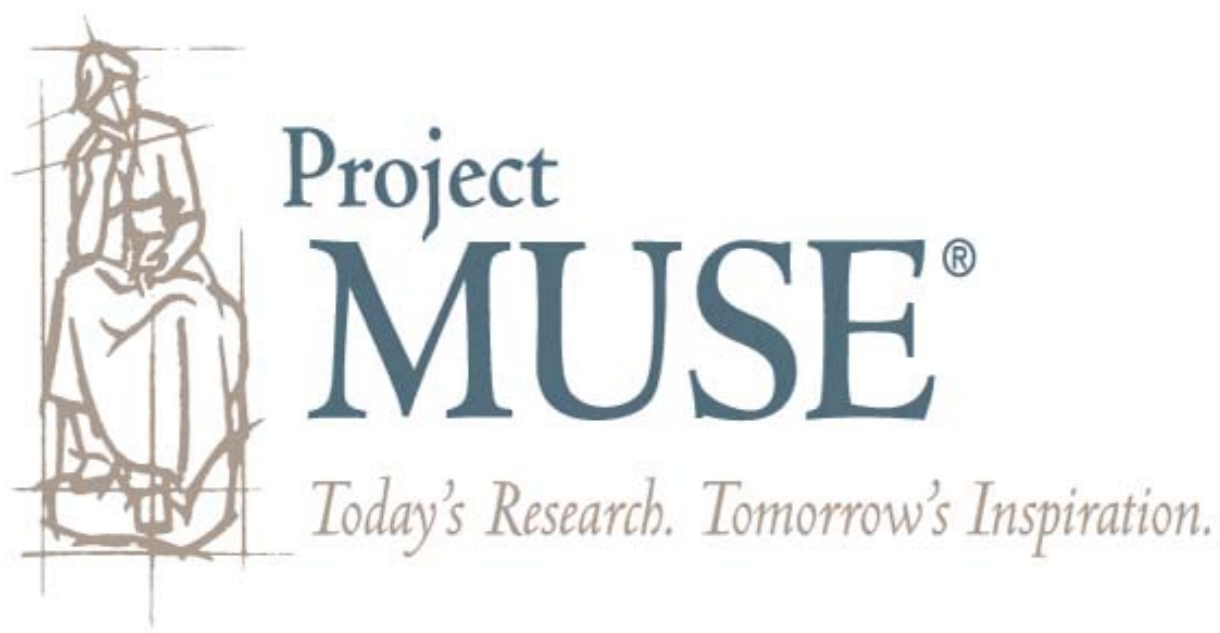




\section{Ambivalence about the Angelic Life: The Promise and Perils of an Early Christian Discourse of Asceticism}

\section{ELLEN MUEHLBERGER}

The equation of the ascetic life with "the angelic life" permeates ancient writing about the renunciatory efforts of Christians; indeed, contemporary scholars often use this same discourse as shorthand for the ascetic movement in Christianity. While the analogy between renunciation and angels began as an inventive exegetical extension of a gospel story, it found traction among the fourth-century bishops who were pressed to make sense of new ascetic movements in their territories. Those in late ancient renunciatory communities knew that lay Christians referred to them as "living the angelic life," and community members put this trope to use among themselves: by envisioning angels as a constant audience for their practices, ascetics created and sustained the boundaries between their communities and the world. Imagining ascetic communities to be places where angels could appear at any moment also created constructive solutions for the sometimes difficult navigation between the strict ideal of perfection in virtue and the flexibility demanded by life in community. At the same time, angelic appearances generated their own difficulties on occasion-both conflicts of authority and crises of identity. Far from an entirely positive identification, being thought of as living "the angelic life" was a prospect received in ascetic literature with ambivalence, and at times disdain.

Parts of this essay were presented at the June 2005 meeting of NAPS, the November 2005 meeting of SBL, the November 2005 meeting of the Ancient Studies Colloquium at Indiana University, and at a March 2007 colloquium of the Religious Studies faculty at the University of the South; I am grateful for the comments I received from each of these audiences. The essay as a whole was improved by the suggestions of David Brakke, J. Albert Harrill, Steven Weitzman, Constance Furey, Mark Graham, and Gina Brandolino, as well as the anonymous reviewers for JECS. 
Near the end of the fourth century, a small group of monks from Palestine traveled to Egypt, there to observe the way of life of the ascetics living in the desert. One of the travelers gave an account of the journey and the wonders he beheld, which begins:

I saw many fathers living the angelic life as they went forward in the imitation of our divine savior, and I saw other new prophets who have attained a divine state by their inspired and wonderful and virtuous way of life. As true servants of God, they do not worry about any earthly matter or consider anything temporal, but while dwelling on earth in this manner they have their citizenship in heaven. ${ }^{1}$

This is the opening to the Historia Monachorum in Aegypto which is only one of a large number of texts from Christian antiquity that utilize the special lens of the "angelic life" for viewing the feats of those ascetics who renounced sex, family, and food to adopt a new lifestyle. The equation of the ascetic life with the angelic one is a theme that permeates ancient writing about the renunciatory efforts of Christians.

It also permeates twentieth-century scholarly treatments of asceticism in late antique Christianity. Between the 1930s and the 1960s, at least four monographs and twice as many articles on this topic appeared in French and German, the majority of which attempted to account for the novelty of the ascetic movement by asserting that the imitation of angels was the driving force of this new development three hundred years after the life of Jesus. ${ }^{2}$ Perhaps the most well-known of these studies is Karl Suso Frank's

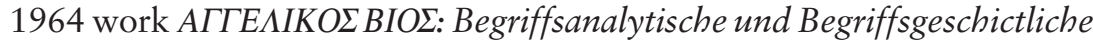
Untersuchung zum "engelgleichen Leben" im frühen Mönchtum. ${ }^{3}$ It argues that early Christian ascetics understood themselves, even in the smallest facets of their practice, to be imitating angels. Peter Nagel in his 1966 book, Die Motivierung der Askese in der alten Kirche und der Ursprung des Mönchtums, came to a complementary conclusion, having searched for an origin of the Christian ascetic movement and finding it in the idea

1. HM Prologue 5 (A.-J. Festugière, ed. and trans., Historia Monachorum in Aegypto: Édition critique du texte grec, SH 34 [Brussels: Société des Bollandistes, 1961], 7; Norman Russell, trans., The Lives of the Desert Fathers: The Historia Monachorum in Aegypto, Cistercian Studies 34 [Oxford: Mowbray; Kalamazoo, MI: Cistercian Publications, 1981], 49-50).

2. These more specific volumes were in large part inspired by Karl Heussi's Der Ursprung des Mönchtums (Tübingen: Mohr Siebeck, 1936), which laid out several different explanations for the origin of the monastic project.

3. АГГЕАIКОГ ВIOL: Begriffsanalytische und Begriffsgeschictliche Untersuchung zum "engelgleichen Leben" im frühen Mönchtum (Münster: Aschendorffsche Verlagsbuchhandlung, 1964). 
of enacting the angelic life. ${ }^{4}$ While the heyday of studies of this "angelic life" was over in the late 1960s, the trope did not drop out of circulation entirely. More recent scholarly work, particularly in English, also references early Christian ascetics as those who live the "angelic life." Robin Lane Fox's popular book, Pagans and Christians, dedicates an entire chapter to asceticism with the title "Living like Angels." A scholar no less impressive than Peter Brown discusses Syriac ascetics under the rubric "These are our angels" in his book about late antique asceticism, The Body and Society. ${ }^{6}$ Robin Darling Young uses the angelic life as a lens through which to interpret Evagrius's comment in Letter 55 that the family of a monk can gain "the inheritance with those being made holy in light," a reference to Colossians 1.12. In his study of the way monastic society influenced the scriptural culture at the heart of early Christianity, Guy Stroumsa finds the practice of writing one's thoughts an integral part of the "bios angelikos which the monks are supposed to lead." The concept of the vita angelica served as a heuristic tool for medievalist Dyan Elliott to study Tertullian's configuration of female virgins as equal to angels in stature, but separate from them in their flesh. ${ }^{7}$ In accounts both academic and religious, it is easy to find ascetics-whether those in the deserts of antiquity or those in the monasteries of modernity-described as living the angelic life.

What does it mean when those in antiquity-or even modern scholarstalk about early Christians "living the angelic life"? That is, if ancient

4. Die Motivierung der Askese in der alten Kirche und der Ursprung des Mönchtums (Berlin: Academie-Verlag, 1966). See also Uta Ranke-Heinemann, "Zum ideal der vita angelica im frühen Mönchtum," Geist und Leben 29 (1956): 347-57; E. V.

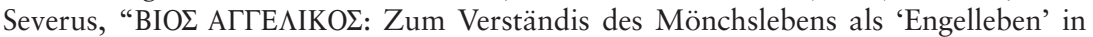
der christlichen Überlieferung," Liturgie und Mönchtum 21 (1960): 73-88. Other, more overtly confessional sources also link ascetic and monastic lives with angels; as examples, see P. Klemens Nachtlberger, "Engel und Mönch," Seckauer Hefte 7 (1938): 11-13; and Agnès Lamy, "Bios Angelikos," Dieu vivant 7 (1946): 59-77.

5. Robin Lane Fox, Pagans and Christians (New York: Knopf, 1986).

6. Peter Brown, The Body and Society: Men, Women, and Sexual Renunciation in Early Christianity (New York: Columbia University Press, 1988).

7. See Robin Darling Young, "Cannibalism and Other Family Woes in Letter 55 of Evagrius of Pontus," in The World of Early Egyptian Christianity: Language, Literature, and Social Context (Washington, DC: Catholic University of America Press, 2007), 130-39. The phrase which Young translates as "those being made holy in light" corresponds in Syriac to the "saints in light" of Colossians 1.12. She sees this as a reference to "those becoming angelic-here surely the monastic community, typically self-described as living the angelikos bios" (137). See also Guy Stroumsa, "The Scriptural Movement of Late Antiquity and Christian Monasticism," JECS 16 (2008): 61-77, at 75. Lastly, see Dyan Elliott, "Tertullian, the Angelic Life, and the Bride of Christ," in Gender and Christianity in Medieval Europe: New Perspectives, ed. Lisa 
Christian ascetics are mainly recognizable to us by the feats they are said to have achieved with their bodies, what did it accomplish to associate them and their practices with beings primarily identified with incorporeality? In this essay, I will first trace the development of the discourse that links ascetic practices with "the angelic life," then will examine how this discourse functioned in the Christian ascetic communities of the fourth and fifth centuries.

While the analogy between renunciation and angels began as an inventive exegetical extension of a gospel story, it found traction among the fourth-century bishops who were pressed to make sense of the new ascetic movements in their territories. As for the ascetics, it is clear that most of them knew their fellow Christians thought of them as living like angels. Those in renunciatory communities even put the trope of "living the angelic life" to use among themselves: by envisioning angels as a constant audience for their practices, ascetics created and sustained the boundaries between their communities and the world. Taking the angelic designation to heart and imagining ascetic communities to be places where angels could appear at any moment also created constructive solutions for the sometimes difficult navigation between the strict ideal of perfection in virtue and the flexibility demanded by life in community. However, angelic appearances sometimes generated their own difficulties-both conflicts of authority and crises of identity. Far from an entirely positive identification, being thought of as living "the angelic life" was a prospect received in ascetic literature with ambivalence, and at times disdain.

\section{“ANGELS IN THE FORM OF HUMANS"}

The first widespread use of the angelic epithet among Christians to describe a particular practice lies in the late third and early fourth century with the development of a discrete lifestyle of sexual renunciation within Christianity. ${ }^{8}$ Even though sexual renunciation was a common component of the

Bitel and Felice Lifshitz (Philadelphia: University of Pennsylvania Press, 2008). I thank Dyan for sharing an advance copy of her essay with me.

8. Some earlier Christian writers had used the language of being "equal to the angels" as a reference for virginity; see Elliott, "Tertullian, the Angelic Life, and the Bride of Christ." Others had used it for an advanced state of Christian living; Clement of Alexandria refers to Christians who are advanced in their development as "equal to angels" in Paed. 1.36.6 and Str. 6.105.1 and 7.57.5. I thank Judith Kovacs for drawing these references to my attention. My interest here lies with the application of this discourse, associated with the phrases "equal to the angels" or "living the angelic life," to particular ascetic practices in the fourth and fifth centuries. 
culture of later monastic communities that constructed themselves as an alternative to an urban lifestyle, historians have demonstrated that it was first a practice adopted by men and women who otherwise maintained normal social relationships and remained in their towns and villages. Dedicated to being virgins, these Christians enacted different models of sexual renunciation; two of the most significant were men and women who lived together, but remained chaste, and women who declared themselves virgins, declining to marry and living with their families. ${ }^{9}$

The adoption of a life of sexual renunciation by so many Christians inspired a profusion of texts that reflected on virginity and the young people who decided to dedicate themselves as virgins. ${ }^{10}$ Some gave practical advice to the fathers whose daughters lived as virgins in the family home, as forms the anonymous text Peri Parthenias, while others, such as Gregory of Nyssa's Treatise on Virginity, visualized the character of virginal purity. ${ }^{11}$ Though approaches to the topic could be abstract or concrete, almost all treatises on virginity commented on the superiority of the lifestyle and the unsurpassed purity of the virgins themselves. While there were many ways to translate the admirable and transcendent nature of sexual renunciants, one particularly compelling way was to adopt the language, inspired by the gospels, that compared virgins to angels.

Authors writing about virginity used primarily the synoptic story of the Sadducees' challenge to Jesus regarding the resurrection to make this comparison (Mark 12.18-27; Matt 22.23-33; Luke 20.27-40). The Sadducees were known to reject the idea that a soul endures after the death of the body (and thus the possibility of resurrection). ${ }^{12}$ In this passage, they pose a question to Jesus: if a woman is married seven times in this life,

9. Susanna Elm, "Virgins of God": The Making of Asceticism in Late Antiquity (Oxford: Clarendon Press, 1994), viii, ix, 29-39. See Elm's discussion of the shift from several different species of female virginity toward monastic structures, facilitated by the rhetorical redefinition of models of piety by bishops and other Christian writers, in Virgins, 373-85. See also Andrea Sterk's review of the earliest developments in Christian asceticism and note the recent turn in scholarship toward finding diversity rather than unity in the origins of asceticism: Renouncing the World Yet Leading the Church: The Monk-Bishop in Late Antiquity (Cambridge, MA: Harvard University Press, 2004), 13-34.

10. For one reading of the genre of virginity sermons, see Thomas Camelot, "Les traités 'de virginitate' au IV siècle,” Études carmélitaines 31 (1952): 273-92.

11. Peri Parthenias (D. Amand de Mendieta and M. Ch. Moons, "Une curieuse homélie grecque inédite sur la virginité adressée au pères de famille,” RBen 63 [1953]: 18-69, 211-38); Gregory of Nyssa, De virginitate (M. Aubineau, ed., Grégoire de Nysse: Traité de la virginité, SC 119 [Paris: Éditions du Cerf, 1966]).

12. Compare Josephus J.W. 2.165 as well as Ant. 18.16, two passages where Josephus reports on the Sadducees' ideas about the mortality of the soul. 
who is her husband in the resurrection? For early readers of the story, the reality of the resurrection was the most salient lesson to be drawn from Jesus' response to the question. At the point when ascetic practice became more popular among Christians, a new lesson emerged. ${ }^{13}$ Christians read Luke's version of the story in particular and saw in it an affirmation that the life of the resurrection was also available before death to those on Earth who declined to marry. Luke depends on Mark for this story, sharing the narrative details of the conflict between Jesus and the Sadducees almost verbatim; however, the specific words that Luke chooses for Jesus' answer to the question about the resurrection differ greatly from those in Mark. In Luke, Jesus responds:

The sons of this age marry and are given in marriage, but those who happen to be judged worthy of that age and of the resurrection from the dead neither marry nor are given in marriage. Indeed, they cannot die anymore, since they are equal to the angels and are sons of God, being sons of the resurrection. (Luke 20.34-36)

Two features of this version of Jesus' answer produce a particular emphasis on the unmarried state. First is the way Luke distinguishes between those who marry and those who do not. Jesus' words make a distinction

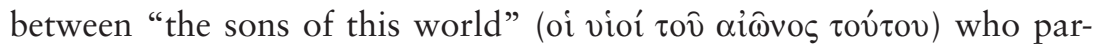
ticipate in marriage and those, on the other hand, "who happen to be judged worthy of that world and of the resurrection from the dead" (oi $\delta \grave{\varepsilon}$

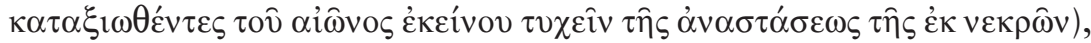
who do not participate in marriage rituals. It appears that those who do not marry have not yet died: these people are simply those "considered worthy" of the next world, not those who have already passed on to it. In fact, these people "cannot die anymore," another detail that suggests Luke is addressing two groups of people among the living: those who have married and those who have not. Luke's version of the answer also differs from Mark's in the way Jesus expresses the similarity between these unmarried people and angels. For Mark, those who are resurrected are "like angels"

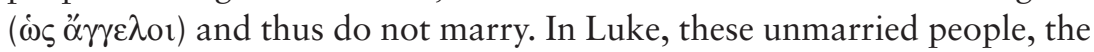
ones who are "considered worthy of ... the resurrection," are "equal to

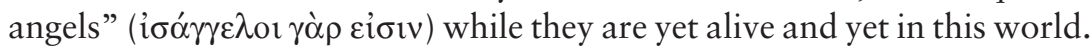

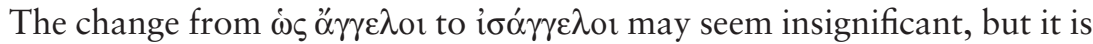
quite provocative: constructive readers understood Luke's version of this story to mean that those who decline marriage in this life achieve a status equal to angels while they are yet very much alive-and human.

13. Elizabeth Clark, Reading Renunciation: Asceticism and Scripture in Early Christianity (Princeton, NJ: Princeton University Press, 1999), 199-200. 
The idea that renunciation of sexuality might, in some way, make human beings "equal to angels" was a powerfully attractive metaphor for the writers who sought to articulate the place of virginity in early Christian practice. A classic text in praise of sexual renunciation, Gregory of Nyssa's Treatise on Virginity (371 C.E.), alludes to Luke's version of Jesus' exchange with the Sadducees as Gregory explains the status of the virgin. ${ }^{14}$ In his reasoning, a virgin may claim the benefits of the resurrected life as a result of his renunciation of sexuality:

For if the life after the resurrection promised to the righteous by the Lord is equal to the angels, and if being set free from marriage is indeed part of the angelic nature, he has already received the benefits of the promise, mingling "with the brilliance of the holy ones" (Ps 110.3) and imitating the purity of the incorporeal ones by the undefiled nature of his life. ${ }^{15}$

Here, Gregory makes explicit what is implicit in Luke 20: not only will humans refrain from marriage in the resurrection, but those who remain unmarried now are already considered righteous, having "already received the benefits" of the resurrection. ${ }^{16}$ By being pure in this way, virgins imitate angelic purity and may even "mingle" with angels, the "holy ones" of Ps 110. As Gregory links virginity in its "undefiled nature" to a life equal to angels, he also elaborates on the activities of angels. For Gregory, virginity is more than the absence of marriage; it primarily involves the cultivation of the soul through the contemplation of the beautiful. Consequently, one of his main interests is to describe how one might protect the soul from disturbance; by releasing attachments and distancing the soul from things liable to change, one can maintain a pure state of contemplation. That means, in essence, being

distant from the things of this impassioned and fleshly life; rather, to make any sympathy for one's own body an alien thing, so as to avoid coming to depend on the things borne of the flesh by [living] the life of the flesh. It means living the solitary life and imitating, as much as is possible, the community of the incorporeal powers, who "neither marry nor are given in marriage," but whose work, attention, and perfection comprise contemplating the father of incorruptibility and making their own form

14. See Aubineau, Grégoire de Nysse, 25, for the date.

15. De virg 14.4 (Aubineau, Grégoire de Nysse, 440-43). This passage, Aubineau notes, has an almost direct parallel in the Sermo Asceticus attributed to Basil of Caesarea (443 n. 3). For a discussion of those sources that may have influenced Gregory, including Methodius and Basil of Ankyra, see Aubineau, Grégoire de Nysse, 97-142.

16. Basil of Ankyra, who may have influenced Gregory's writing, goes further by saying that virgins are "already angels on Earth" (virg. 37 [PG 30:744], cf. 51 [772]). 
nearer to the beauty of the archetype through the imitation that is allowed them. ${ }^{17}$

Equally influenced by Platonic advice regarding the contemplation of the beautiful and the belief that angels do not participate in marriage, Gregory constructs a two-part model for virgins to imitate "the incorporeal powers": the person who attempts virginity should adopt the ways of angels, both their unmarried state and their contemplation of that which is above them. Virgins can only imitate angels in their actions, but cannot identify as angels: they remain below, relegated-as angels are- to the "imitation that is allowed them."

A more expansive view of the status of virgins underlies a treatise on virginity that survives in Syriac, once attributed to Athanasius but now recognized as pseudepigraphical. ${ }^{18}$ The author addresses female virgins, who, instead of living in their homes with their families, have adopted separate communities; he encourages them, speaking to each individually,

[t] oward the heavenly light you too have been summoned, illustrious bride, and to the lifestyle of the angels, as also their companion on account of the brilliance of the lofty beauty of virginity and the perpetuity of the unending glory. Therefore, even the angels honor the excellence of her (virginity's) splendor as their equal. ${ }^{19}$

The equation of the unmarried state and angels in Luke's passage informs this author's concept of virginity, to be sure, but these women do more than simply avoid marriage. Rather, they adopt the "lifestyle of the angels," both beautiful and glorious. In this, they are more than just "equal to the angels," because the virginity they practice is actively honored by the angels as their equal. Angels are not the object of their imitation, as in Gregory's Treatise on Virginity, but rather act as the voice that approves these virgins' new and separate community of chastity.

If this text presents a wider and more complex view of virginity, it is also more complex in its view of what angels are. Even if virgins can attain a state equal to angels by enacting a certain set of practices, angels are still

more sublime than people . . because angels are not given in marriage nor are married, still they are not entangled in flesh and blood, nor do they

17. De virg. 4.8 (Aubineau, Grégoire de Nysse, 328-31).

18. David Brakke, ed., Pseudo-Athanasius On Virginity, CSCO 592 (Leuven: Peeters, 2002), x-xii.

19. On Virginity 42 (CSCO 592:17; trans. CSCO 593:16). 
have a dwelling place on earth, nor are they occupied with the multitude of desires, nor do they need food and drink, nor is a sweet tone able to wound them, nor too an illustrious sight to make them bend down. Rather, just as with the sun at midday one sees evenly the extent of its transparency with nothing to mar it, so too with the nature of the angels: there is not a single desire to mar it. ${ }^{20}$

Angels, it is true, do not participate in marriage. However, they have several other characteristics as well: they do not have flesh, nor desire, do not need food or drink, and, apparently, are entirely transparent. In all of these things, angels are "more sublime than people," to be sure, but the very words used by this text to describe angels are based on assumptions about virgins. Virgins are indeed "entangled in flesh and blood," they do "have a dwelling place on earth," they are "occupied by the multitude of desires," they do need food and drink. The effect of listing the attributes of angels in this way - as the photographic negative of the human condition-is, ultimately, to praise human virgins. To the extent that a virgin is successful in her pursuit of purity, she is more than equal to angels, because to accomplish her goals while burdened with the desires and flaws of the flesh, she must surpass the effort of angels, who have no such burdens.

Ultimately, writers began to describe other ascetic lifestyles, ones encompassing more than the renunciation of sex, with a discourse that emphasized the "angelic" nature of these lifestyles. As more ascetic practices came to be associated with the angelic life, angels as imagined by Christians came to resemble those who took up such practices. For example, John Chrysostom was clearly aware of the references in the New Testament to multiple levels of angels. In one of his baptismal homilies, he reminds his catechumens that the martyrs of the past overcame their physical pain by thinking on heavenly things. "That is why," he says,

that blessed apostle, who knew the strength of such counsel, told us to mind the things that are above, where Christ is seated at the right hand of God [Col 3.1]. See the sagacity of our teacher and to what a height all at once he raises those who heed him. He cut a path through the midst of all the angels, archangels, thrones, dominations, principalities, virtues, all those invisible powers, the cherubim and seraphim, and set the thoughts of the faithful right before the very throne of the King. ${ }^{21}$

20. On Virginity 45 (CSCO 592:18; trans. CSCO 593:17).

21. Chrysostom, Baptismal Homilies 7.20 (Paul W. Harkins, ed., St. John Chrysostom: Baptismal Instructions, ACW 31 [New York: Newman Press, 1963], 112). In addition, see Baptismal Homilies 1.2 (Harkins, Baptismal Instructions, 23); and To Orosius against the Priscillianists and Origenists 11.14. 
In order to reassure Christians who suffer that they have direct access to the power of God through Christ's intervention, Chrysostom pieces together the different orders of angels that are mentioned in Scripture and then depicts Christ traveling up through these successive orders. As he portrays it, angels are at the lowest level, followed by archangels, thrones, and others on up to the seraphim and cherubim who surround God. The rhetorical effect of mentioning all of these levels of angels is to emphasize Christ's mediating power, now made available to new Christians; their prayers bypass the heavenly middlemen and go straight to the top. Long before the appearance of the famous sixth-century text detailing the Celestial Hierarchies, Chrysostom was cognizant of multiple orders of angels and could use that idea to make a point to his catechumens.

It is striking, then, that in another context, Chrysostom defines angels precisely by their lack of hierarchy. In his treatise, Against the Opponents of the Monastic Life, Chrysostom attempts to reassure frightened parents of those thinking of entering the monastery. These worried parents think that if their child were to disengage from marriage and family-as the monastic lifestyle requires-it would reflect negatively on the care they, as parents, have provided. Chrysostom agrees with them about the gravity of their situation: neglecting the welfare of one's children, he acknowledges, is among the highest of sins and will be punished by God. ${ }^{22}$ However, he points out, parents who consider entry into the monastery the equivalent of neglect are mistaken: their children are actually better protected in the monastery than in society, because it is a place that allows them to avoid confusion and injustice. Only those in monasteries

live in tranquility, in the harbor, in great security, observing the shipwrecks of others, as if from heaven. For they have chosen a way of life which befits heaven, and they have attained a state inferior in no way to that of angels. Just as among the angels there is no inequality, nor do some enjoy prosperity while others experience misery, but all of them share one peace, one joy, one glory, so it is likewise in the monasteries. No one reproaches poverty, no one exults over wealth. That "yours" and "mine" which overturns and upsets everything is utterly banished. All things are held in common-food, housing, clothing. ${ }^{23}$

22. Oppugn. 3.4 (trans. David G. Hunter, A Comparison between a King and a Monk / Against the Opponents of the Monastic Life: Two Treatises by John Chrysostom, Studies in the Bible and Early Christianity 13 [Lewiston, NY: The Edwin Mellen Press, 1989], 132). Cf. Sterk's mention of a similar viewpoint of monasticism, Renouncing Yet Leading, 22-23.

23. Oppugn. 3.11 (Hunter, Two Treatises by John Chrysostom, 146-47). Hunter notes that there is a very similar passage in Chrysostom's Hom. in Matt. 72.3 (PG 58:671-73). 
Chrysostom has perceptively identified the source of the parents' fear: if marriage and family are primary guarantors of social standing and financial security, aren't parents who allow their children to opt out of marriage and its benefits irresponsibly endangering their children's future security? No, Chrysostom implies. Entering the monastery actually ensures that security. Even if there is no prosperity among its members, there is no poverty, either. All monks are of equal status, and that status happens to be "in no way inferior to that of the angels."

Chrysostom identifies life in the monastery with life in heaven and singles out one thing as the most prominent feature of this life: the total equality among members. It may not be remarkable to say that angels are not distinguished by wealth or poverty; even the earliest gospel telling of the story of Jesus being questioned by the Sadducees acknowledges that angels live free from the mundane and the material. But, to say that among angels there is "no inequality," that they "share one glory," is indeed remarkable, particularly for a writer who has in other contexts made reference to the hierarchical nature of the heavenly orders. Chrysostom's idea of an equal community of angels is clearly influenced by his view of monastic life. As much as monks are like angels, angels are-in this text-a lot like monks.

We should not be surprised, then, that Chrysostom speaks of the ascetics living outside of Antioch, those who have abandoned society and even the bounds of the monastery, as "angels in human form" waiting to be seen. He does so at the beginning of a series of homilies on the gospel of Matthew, a set of pieces notable for the way they urge listeners to go and visit these "angels," even if they must travel to do so. ${ }^{24}$ When some ascetics happen to visit his congregation, Chrysostom tells the members of his church not to miss the opportunity to observe their holiness: "Lest we neglect their virtue as we consider their simple appearance and the language they speak, let us observe well and accurately their angelic life, the philosophy they enact." 25

A number of Christians followed the advice of orators like Chrysostom: when the population of ascetics living in the Egyptian desert rose, so did the number of pilgrims who traveled to see them. As the angelic and otherworldly character of the communities in the desert was presented to congregations of urban Christians, "some men and women became so

24. Hom in Matt 8.5 (PG 57:87-88); this is also not the only place where Chrysostom refers to monks as "angels" or living the "angelic life." See also, In Epist. 1 ad Tim. 14 (PG 62:575): "they, being holy, are indeed angels in the form of humans."

25. 8.4-5 (249-50), quotation at 8.4 (249). 
deeply attracted to this world that they set out to see the living saints for themselves." ${ }^{26}$ The numbers of pilgrims were so great, Georgia Frank points out, that even those writers who recorded the journeys of a single group to see ascetics could not help but notice that their protagonists were hardly alone. Theodoret, in his compilation of stories collected by pilgrims like himself, says that there were so many visitors to these ascetic practitioners that every road looked like a river, with pilgrims streaming along. ${ }^{27}$

The accounts of these pilgrims suggest that they were influenced by the discourse that equated ascetics with angels. The narrator of the Historia Monachorum in Aegypto, cited at the start of this essay, describes the ascetics his group visited as "angels." He promises to have seen something otherworldly-humans who are "new prophets" and living in a "Godlike state." The ascetics locate their bodies in the desert, but their lives are lived in heaven. Having prepared its readers in this way, the text does not disappoint expectations that ascetics will resemble angels. The Historia Monachorum takes the angelic metaphor as a physical reality, its preferred way of depicting the appearance of monks being to attribute to them angelic qualities such as lustrous and shining faces. ${ }^{28}$ For example, the author visits Abba Or and reports that he "looked just like an angel. He was about ninety years old and had a snowy white beard down to his chest. And his face was so radiant that the sight of him alone filled one with awe." ${ }^{29}$ For others it is their carriage that earns them the epithet "angelic." Abba Bes, who "surpassed everyone in meekness," "lived a life of utmost stillness, and his manner was serene, since he had attained the angelic state." ${ }^{30}$ Theon's ability to heal prompts the author of Historia Monachorum to label his appearance that of an angel: "A crowd of sick people went out to see him every day, and laying his hand on them through the window, he would send them away cured. One could see him with the

26. The Memory of the Eyes: Pilgrims to Living Saints in Christian Late Antiquity (Berkeley and Los Angeles: University of California Press, 2000), 2.

27. H. rel. 26.11 (Pierre Canivet and Alice Leroy-Molinghen, ed. and trans., Théodoret de Cyr: Histoire des moines de Syrie, SC 234, 257 [Paris: Éditions du Cerf, 1977, 1979], at 257:182). Cited by Frank, Memory of the Eyes, 2. For more evidence that the numbers of pilgrims bound for ascetic viewing were high, see Frank's list of references here, n. 4.

28. Patricia Cox Miller treats this style of depiction in $H M$ as well as other works in her well-known article, "Desert Asceticism and the Body from Nowhere," JECS 2 (1994): 137-53.

29. HM Abba Or 1 (ed. Festugière, Historia Monachorum, 35; ed. Russell, Lives of the Desert Fathers, 63).

30. HM Abba Bes 1 (ed. Festugière, Historia Monachorum, 40; ed. Russell, Lives of the Desert Fathers, 66). 
face of an angel giving joy to his visitors by his gaze and abounding with much grace." ${ }^{31}$ In some cases, the epithet extends to an entire community, as was the case with those who were living with the ascetic Apollo: they looked like "a real army of angels." 32

By the time of the writing of the account of Historia Monachorum, its author could use the metaphor of "ascetic as angel" as a vessel for many different impressive features he perceived among the desert dwellers. While writers who had focused on virginity alone, such as Gregory of Nyssa, drew a link between the rejection of marriage and a status equal to angels in their reading of Luke 20, other writers applied the angelic discourse to these more complex systems of renunciation. For bishops looking to promote and sanctify the growing movement toward ascetic practice, the designation of ascetic lifestyles as "angelic" was a powerful rhetorical tool-so powerful that in some cases, its use redefined the nature of angels as it linked their glory to the glory of human ascetics. These ascetics also seemed to understand that others conceived of them this way.

\section{SUSTAINING COMMUNITY: THE ROLE OF ANGELS}

Even in antiquity, Egypt was widely recognized as the birthplace of Christian ascetic practice. ${ }^{33}$ Two kinds of literature survive from the ascetic and monastic movements in Egypt. There are texts written by and about monastic leaders, such as those which we have from Shenoute's White Monastery or the materials related to the Pachomian federation. On the other hand, there are several collections of sayings and traditions of Egyptian monks, none of which were actually compiled in Egypt: the Historia Monachorum,

31. HM Theon 1 (ed. Festugière, Historia Monachorum, 44; ed. Russell, Lives of the Desert Fathers, 68).

32. HM Apollo 18-19 (ed. Festugière, Historia Monachorum, 54; ed. Russell, Lives of the Desert Fathers, 73): "A community of brothers formed itself around him [Apollo] on the mountain, as many as five hundred of them, all sharing a common life and eating at the same table. [19] One could see them looking like a real army of angels, drawn up in perfect order, robed in white, and realising in their own lives the text of Scripture which says, 'Be glad ye thirsty desert; break forther into singing thou that didst not travail with child; for more are the children of the desert than the children of the married life' (Is. 31.1; 54.1)."

33. Even if there is no one single point of origin for the Christian ascetic movement of late antiquity, it is clear that the diverse traditions that represent the start of ascetic practice mostly began in Egypt, with others in Syria. See James Goehring, "The Origins of Monasticism," in Ascetics, Society, and the Desert: Studies in Early Egyptian Monasticism, Studies in Antiquity and Christianity (Harrisburg, PA: Trinity, 1999), 13-35. 
again, is the report of a group of Palestinian monks who visited Egypt; Palladius's Lausiac History is based in part on his experiences during an eight-year stint in the Egyptian desert, but was written long after his departure; and the Apophthegmata texts appear to have been redacted in Palestine in the wake of the Origenist controversy, the result of a preservationist tendency that arose when it became clear that the Egyptian model of monastic life was quickly changing. ${ }^{34}$

From a careful analysis of both types of texts, we find that ascetics understood the idea of living "the angelic life" as more than just the praise heaped on them by non-ascetic Christians; it was also adopted as one way for them to frame their own experiences. The literature from and about the ascetic movement in Egypt suggests that the angelic discourse operated in the lives of ascetics, shaping the bounds of community and determining acceptable behavior, often through the assumption that ascetics were somehow like and could expect to see angels. In some cases, the angelic appearances in these texts provided tools for navigating the conflicting demands of different virtues idealized in ascetic communities. However, such appearances also created problems of authority and status for the ascetics portrayed in this literature.

There were many ways that the idea of an "angelic life" lived in the desert served ascetic communities constructively. Most ascetic literature made a sharp distinction between the community of ascetics and the rest of the world, and an analogy between a life of renunciation and the life of the angels made this distinction even sharper. Two Apophthegmata Patrum collections report a story about a pair of ascetics who are forced to make a choice:

Two brothers who were attacked by fornication went away and took wives. Afterwards, they said to one another, "How have we benefitted by deserting the angelic order and coming to this impurity? And after that won't we come into the fire and into torment? Let us therefore go back to the desert and repent about what we have done." 35

For these brothers, there are but two options: either life with women (and by extension, with society), or the "angelic order" of life in the desert. By the lights of this rhetoric, these men must decide between a present and

34. David Brakke, Demons and the Making of the Monk: Spiritual Combat in Early Christianity (Cambridge, MA: Harvard University Press, 2006), 127-28.

35. Verba sen. 5.5.34 (PL 73:882D). A longer version of this anecdote occurs in the Greek anonymous collection, N186 (ed. F. Nau, "Histoires des solitaires égyptiens," ROC 13 [1908]: 272). One anonymous reviewer for JECS pointed out that "the shorthand reference of 'taking wives" in this story may be an allusion to Luke's distinction between humans who marry and angels who do not marry. 
possible heaven and a delayed but inevitable hell. The physical distance between the "desert" communities of Egypt and the towns and villages they renounced was, as James Goehring has pointed out, not that large; ${ }^{36}$ however, to suggest that ascetics are part of an angelic order is to create a gulf of supernatural proportions between their society and that of lay Christians. In this way, the understanding that ascetics in the desert were living the life of the angels-a notion which, in the case of orators like Chrysostom, spurred an injunction to observe such ascetics and adopt some of their practices-actually created a distance between those in the desert and the rest of the world, rather than making ascetics more accessible to lay Christians. Built into statements about the angelic life among ascetics is the assumption that to live in the desert meant to forsake utterly one's former mundane relationships as a requirement of membership, even relationships with Christian family members. ${ }^{37}$ As Evagrius promises, "whoever keeps the commandment of God and rejects the world will not be put out of the community of angels." ${ }^{38}$

Remaining within the ascetic community had benefits beyond the vague promise of being part of an "angelic order." The equation of renunciation with the angelic life created expectations about angels appearing to and living among members of ascetic communities, expectations which were primarily operative within the literature that represented these communities to others. For example, Palladius assumed that because ascetics lived in community with angels, they could expect some degree of angelic help in their labors. In the Lausiac History, angels appear and help ascetics do the physically impossible_-or at least those tasks that may seem physically impossible to the reader. For instance, angels appear in order to help ascetics manage the difficulty of sexual renunciation and its requirements. In one case, an angel appears to Amoun of Nitria and transports him across a river he is trying to ford, thus preventing him from having to take off his clothes and appear nude in front of others. ${ }^{39}$ Another ascetic, Elias, was overwhelmed at his task of taking care of 3,000 female virgins; apparently, this large number of nubile young women was almost too much for Elias's

36. Goehring, “The World Engaged: The Social and Economic World of Early Egyptian Monasticism," in Ascetics, Society, and the Desert, 39-52.

37. Bentley Layton, "Rules, Patterns, and the Exercise of Power in Shenoute's Monastery: The Problem of World Replacement and Identity Maintenance," JECS 15 (2007): 45-73.

38. Cent. 4.74 (W. Frankenburg, ed., Evagrius Ponticus [Berlin: Weidmannsche buchhandlung, 1912], 307).

39. H. Laus. 8 (Cuthbert Butler, ed., The Lausiac History of Palladius [Cambridge, 1904], 28-29); cf. v. Anton. 60 (G. J. M. Bartelink, ed., Vie d'Antoine, SC 400 [Paris: Éditions du Cerf, 1994], 294-96). 
temperament. Three angels come to him in a vision and helpfully castrate him, allowing him to keep up his work..$^{40}$ Even if sexual temptation overwhelms the ascetic, angels can lessen the negative consequences. According to the Lausiac History, as Evagrius considered his love for a woman he could not have, he envisioned himself being thrown in prison for his impropriety. Though only a daydream, being left alone in prison was so difficult for Evagrius that an angel came to him to keep him company. ${ }^{41}$ These angelic appearances are spectacular, and in their wonder they call attention to the amazing - and in some cases heartbreaking-deeds of sexual renunciation that Palladius witnessed or heard. At the same time, the presence of angels as assistants paradoxically makes these deeds more believable to contemporary readers, because the help of a supernatural entity makes these feats of renunciation seem possible.

The assumption that ascetics live the angelic life also helped members of the ascetic community adopt appropriate behaviors. The imagined presence of angels, for example, can inspire repentance: one saying in the Greek anonymous collection of the Apophthegmata reports that there lived "an anchorite who had settled in the desert in the district of Antinoë and was progressing in virtue." However, he is persuaded by a demon that he needed to be serving others, and thus he left the community to go work in society, unaware he had fallen into a trap:

After a long time, he happened across a woman and having been weakened by his lack of attention and arriving at a deserted place, with the enemy following after, he sinned beside the river. When he took to heart how the enemy rejoiced at his fall, he wished to give up on himself for having so greatly grieved the Spirit of God, the angels, and the holy fathers . . . . ${ }^{42}$

As he repents, the public to whom he imagines himself responsible includes God, those he lives with in the desert, and angels, who observe his action. ${ }^{43}$ To be part of a community of angels meant that angels watch one's behavior and can hold one accountable, even after one has left the community.

If the monk who left to work in the world is held accountable by angels, how much more were so those who stayed? According to the literature that recounts stories of the Egyptian ascetics, angels can, by their very

40. H. Laus. 29 (ed. Butler, Lausiac History, 84-86).

41. H. Laus. 38 (ed. Butler, Lausiac History, 117-18).

42. N175 (ed. Nau, "Histoires des solitaires égyptiens," ROC 13 [1908]: 266-68, cited at 266).

43. Jerome D. Folkman, "The Unseen World in the Minor Midrashim" (Rabbinical thesis, Hebrew Union College, 1931), makes a similar argument about unseen heavenly angels enforcing group behavior. 
appearance, influence the behaviors—and even the speech—of those who remain with their communities. Consider the story told about the discerning monk who has visions of angels:

One of the fathers said that when the elders used to sit around and speak about beneficial matters, there was one among them who could discern things, and he saw angels fanning them with palm branches and praising them. When another matter came up [one that was not beneficial], the angels went away and pigs full of foul odors would wallow in their midst and obliterate them. As soon as they spoke about beneficial matters again, the angels would come and praise them. ${ }^{44}$

There are two ways these visions help create and reinforce the community expectation about good discourse. First, as angels appear and disappear, they provide immediate feedback on the conversation of the group. Second, the presence and absence of the angels allow the discerning brother to avoid direct judgment of the group. Instead, he simply reports what he sees; the angels "speak" for him. This is an important distinction, because according to the virtues idealized in Christian ascetic communities, a monk should at all costs avoid judging another monk. In his work detailing the values that governed the relationships among desert monks, Graham Gould observes that the sheer "number of stories illustrating the necessity of not judging others, and the urgency with which abstaining from judgement was commended, confirms the importance of the problem of judgement" in ascetic literature. ${ }^{45}$ The act of judging represented a lack of humility or the ignorance of one's own sins, and the "possibility of being subject to demonic deceit," not to mention the undue shame it could inflict on the one being judged. ${ }^{46}$

The mechanism by which the manifesting angels save the brother from erring in the vice of judgment is rather simple-either he sees angels or he sees pigs—but the assumption that angels could manifest themselves in monastic communities allowed for elegant solutions to more complex problems, particularly those which arose when the demands of multiple ascetic virtues seemed to clash. Specifically, the imagined presence of angels helped monks and their superiors negotiate the difficult path between avoiding one behavior-slander-and allowing another-heresy. To explore this negotiation, let us consider the fact that while judgment was

44. N359 (ed. Nau, "Histoires des solitaires égyptiens," ROC 18 [1913]: 137).

45. Graham Gould, The Desert Fathers on Monastic Community, Oxford Early Christian Studies (Oxford: Clarendon, 1993), 123, but see also the discussion that ranges over $123-32$.

46. Gould, Desert Fathers, 129. 
indeed considered an act of vice, worse still than judgment was slanderperhaps logically so, because slander involved a third person, a listener, in the act of judging. ${ }^{47}$ As one ascetic describes it, slander comprises "[f]ailure to recognize the glory of God and jealousy toward one's neighbor." 48 In a community that depended on humility and camaraderie, the human urge to talk about one's neighbors could be an insidious force.

It was also a necessary one. In her study of the desert ascetics and their style of communication, Maud Gleason notes that as "we examine the social behavior of these indomitable individuals, the corpus of their sayings and stories yields evidence of two processes characteristic of social groups: status negotiation and behavioral regulation. Gossip played a critical role in both." ${ }^{49}$ If ascetics rejected the usual demonstrations of status as a part of their renunciatory project-eschewing wealth and family connectionssocial prestige as defined by their own community was the last marker of status remaining to them. The stories repeated about a particular ascetic and his deeds of renunciation were the building blocks of his reputation among his peers and even his spiritual progeny. In Gleason's words, "status recognition required gossip." ${ }^{50}$ This view of the necessity of gossip, however, assumes that "gossip" is always positive; negative reports could, of course, be damaging to an ascetic's reputation.

Perhaps this is why the literature representing ascetic communities treats the avoidance of slander as if it were an ascetic practice itself, one at times more important than the more familiar rejections of food, drink, sleep, and sex. A saying of Hyperchios asserts that "it is better to eat meat and

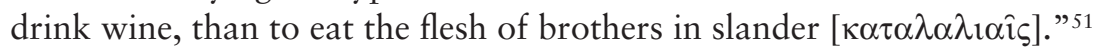
This pronouncement is immediately followed by another that explains the special nature of slander as more than just a sin of the self: "The serpent drove Eve out of paradise through whispering. He who slanders his neighbor is like the serpent, for he both loses the soul of the one who listens, and does not preserve his own." ${ }^{52}$ These sayings, taken together, recognize that

47. At least one saying in the Apophthegmata collections directly contradicts me, saying that to judge another is indeed worse than slander. See N417, cited by Gould, Desert Fathers, 123.

48. AP Isaias 10; I was directed to this reference by its mention and translation in Robert E. Sinkewicz's Evagrius of Pontus: The Greek Ascetic Corpus, Oxford Early Christian Studies (Oxford: Oxford University Press, 2003), 18. For other references to the monastic injunction against gossip, see Sinkewicz, 18, n. 18, 19, and 21.

49. "Visiting and News: Gossip and Reputation-Management in the Desert," JECS 6 (1998): 501-21, at 503.

50. "Visiting and News," 503, emphasis in original.

51. Hyperechius 4 (Gould, Desert Fathers, 121).

52. Hyperechius 5 (Gould, Desert Fathers, 121). 
slander, unlike culinary indulgence, involves more than one member of a community and can be damaging to the whole. Abstention from food is one practice that is compared with slander, abstention from sex another: in sayings attributed to Poemen and Matoes, slander is unfavorably compared with fornication. ${ }^{53}$ Avoiding slander is, in these stories, considered equal to the basic ascetic practices that renounce physical pleasures.

The damaging nature of slander made its avoidance more important than telling the truth. For some monastic leaders, there was no difference between statements made that were false and those that were true: any negative report about another would count as slander and thus be a vice. ${ }^{54}$ Additionally, weigh the message of the following story from the alphabetic collection of the Apophthegmata:

Suppose two men have committed murder before you, and one of them has fled to your cell. Then the magistrate comes to look for him, and asks you whether you have seen a murder[er?]. If you do not lie, you are handing the man over to death. You should leave him before God without censure, for God knows everything. ${ }^{55}$

When one is given the choice between telling the truth and "handing the man over to death" on the one hand or lying and allowing the murderer to go free, this anecdote recommends that one should lie rather than report a brother's transgression, even if that transgression is murder. ${ }^{56}$ With the consideration of the general injunction against slander, this story may be easier to understand: it teaches that the report of another's sin is a breach of community values. Slander is worse than lying, even worse than murder.

Is slander, then, the worst imaginable transgression? According to the Apophthegmata Patrum, one sin topped all others, including slander-heresy. Consider how Agathon, described as a "monk of great discernment," reacts when some brothers come to test him: he admits to a litany of sins, including fornication, pride, and slander, but bristles at the idea that he

53. Gould, Desert Fathers, 121. In Poemen 154, slander and fornication are spoken of in once piece, while in Matoes 8, Matoes discusses with another brother whether slander is worse than fornication. Matoes argues that it is not, with the brother holding the other view.

54. Basil of Caesarea reports that "he who makes a statement against someone in order to slander or disparage him is a detractor, even though the statement be true"; ep. 22.3.8, cited and translated by Sinkewicz, Evagrius of Pontus, 18, n. 18.

55. Alonius 4 (cited in Gould, Desert Fathers, 125).

56. There is, of course, a message about the difference between the community of ascetics and the world of the magistrate in this story; perhaps the meaning of the story lies in keeping the ascetic community a different society by refusing to participate in the juridical system of the world. Even so, it is surprising to see lying portrayed as preferable in this case. 
is a heretic. He explains: "The first things I ascribe to myself, for it is good for my soul, but heresy is separation from God, and I do not wish to be separated from God." ${ }^{57}$ Agathon may be a fornicator, he may even be a slanderer, but he claims that these activities and their consequences ultimately are good for him and his spiritual development. Heresy alone threatens to remove him from community with God.

It can also dissolve an ascetic's bond with the human community. Theodore of Pherme offers the following advice:

If you are friendly with someone, and it comes about that he falls into the temptation of fornication, give him your hand and draw him out. But if he falls into heresy, and you cannot persuade him to return, then quickly cut yourself off from him, lest by delaying you are dragged down with him into the pit. ${ }^{58}$

Fornication, while perilous to the person involved, does not threaten to endanger others around him; heresy is another story.

If slander is to be avoided at all costs, but heresy was such a danger to the community, what should happen if one brother hears that another is entertaining heretical ideas? As Maud Gleason points out, inevitably "word gets out" about deviance in ascetic communities, but how? ${ }^{59}$ How could information about possible heresy pass among the community, or perhaps more importantly, from the community to its leader, without violating the injunction against offering negative reports of others?

No antique source phrases the problem in quite this way. There are, however, stories in the literature about ascetic communities that demonstrate awareness of the dilemma, and these stories suggest that angelic appearances could resolve it. For example, in two texts from the Pachomian community, superiors learn about the heretical dispositions of others through having visions of angels or receiving messages from angels, thus avoiding the more mundane transfer of information from one human being to another and, with it, the prospect of slander. The first text describes how Pachomius himself-here called "the Great Man" or "the Old Man"—is able to sniff out heresy among a group of visitors:

As [the visitors] sat in a secluded cell, the Old Man perceived a strong stench from them. He did not know the cause of such a stench, because he was conversing with them face to face and could not learn the cause by a supplication to God. Seeing their eloquence and their familiarity with the Scriptures, he could not understand their sickening stench. After the Great

57. Agathon 5 (cited in Gould, Desert Fathers, 65).

58. Theodore of Pherme 4 (cited in Gould, Desert Fathers, 93).

59. Gleason, "Visiting and News," 504. 
Man had conversed long with them about the holy Scriptures, and the ninth hour was come, they rose up to go away to their own place ... . The Great Man, in order to know the cause of their stench, went into his cell and prayed God to make it known to him. An angel of the Lord came and told him, "It was some doctrines of impiety from Origen that, in their souls, produced such a stench." 60

In the remainder of the passage, Pachomius calls the visitors back and counsels the brothers not to be acquainted with Origen's books, indeed to "cast them in the river, and never want to read them again, and especially the blasphemous ones." 61

The benefit of angelic visions also applies to Theodore, a later leader of the Pachomian federation. ${ }^{62}$ According to two passages in the Letter of Ammon, Theodore is aware of the heretical deeds of monks hidden away in private cells because angels act as his informants. ${ }^{63}$ In the first instance, a monk accused of improper deeds tries to avoid talking with Theodore about his actions, but Theodore has been given specific information about these hidden deeds and uses that information to persuade the monk to admit his wrongdoing:

60. Paralipomena 7 (Armand Veilleux, trans., Pachomian Koinonia, vol. 2: Pachomian Chronicles and Rules [Kalamazoo, MI: Cistercian Publications, 1981], 28-29).

61. Paralipomena 7 (trans. Veilleux, Pachomian Koinonia, vol. 2, 29).

62. Theodore's appointment as head of the federation was a compromise solution to a dispute about the proper successor to Pachomius. Apparently, the Ep. Amm. is aware of the slight taint surrounding Theodore and in the text, Theodore's leadership is confirmed by angelic appearances: the letter recounts a story in which Pachomius claims that Theodore's appropriateness as successor was clear to him because when Theodore joined the community, an angel appeared to Pachomius to tell him that Theodore was "full of the Holy Spirit," citing Acts 7.55 (James E. Goehring, ed., The Letter of Ammon and Pachomian Monasticism, Patristische Texte und Studien 27 [New York: de Gruyter, 1986], text: 130, trans.: 163-64). In addition to this, while Pachomius is still alive, Theodore has a night vision in which he sees angels enacting a sort of Eucharist at the altar of the church, one in which Theodore himself is fed

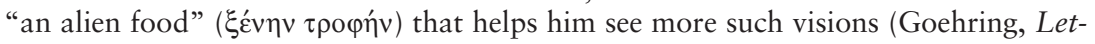
ter of Ammon, text: 134, trans.: 166-67). As James Goehring has pointed out, the Ep. Amm., like most of the extant Pachomian texts, should be dated to the time of Theodore and Horsiesius (ca. 346-400), and thus any story about Pachomius in texts like the Ep. Amm. must be read as representing this later time period's interpretation of Pachomius. That is to say, these appearances have more to do with authenticating Theodore as a leader than they do with reporting Pachomius's experience. See Goehring, "New Frontiers in Pachomian Studies," in Ascetics, Society, and the Desert, 162-86, particularly 163-64.

63. To be fair, I should point out that in two other instances, the text indicates that Theodore receives word of heresy via the Holy Spirit (Ep. Amm. 22, 23 [Goehring, Letter of Ammon, text: 143-46, trans.: 172-74]). 
Theodore appeared at the monastery and called the brothers together. . . And seizing a certain young monk who was coming out of the house, he hauled him into a vaulted room and compelled him to relate what he had done. He explained that he was the one who had been pointed out by the angel and ordered expelled from the monastery. As he did not want to speak, Theodore began to relate his first act and asked whether he had another monk as a sympathizer. Falling at Theodore's feet, he requested him to remain silent with respect to his other acts and to expel [him] from the monastery. ${ }^{64}$

While the passage does not tell us the exact nature of the deed, the act is embarrassing enough for the young monk to decide to leave the monastery once he hears the particulars of his supposedly private actions recounted to him. Theodore used this same tactic more than once; after Theodore had expelled the first monk, "he went to each of the other monks that had been accused by the angel in private at night." As the Letter of Ammon would have it, Theodore apparently received regular, detailed, and frank reports on the activities of monks from an angel.

The deeds of the monks in this first case are implied to be sexual, but a second story about Theodore intimates that he receives reports about heretical teachings promulgated in secret as well:

And once, when Theodore had all the brothers together, he said to Psarphius ... "Send to Palchelphius's cell and have him come here together with the youth that is with him in his cell. And summon also his elder son."

And when they arrived, Theodore said to Palchelphius: "Tell [me] what you were teaching this youth during the night." And he said: "What was I teaching him? The fear of God." Theodore said: "God himself, through an angel, has informed against you. Therefore, tell the truth whether indeed your teaching is a light."

But since he refused, Theodore said to all: "He was teaching him that there is no resurrection of the flesh, reproaching the nature of his flesh." Then, as he said to Palchelphius, "Say whether it is so or not," Palchelphius's son cried out and said: "He also persuaded me to think about these things last evening." 65

The pattern in this story is much like that in the story of the young monk with the embarrassing deed: Theodore learns about covert deviance from an angel and uses this knowledge to his advantage. Even though Palchelphius refuses to confess when confronted, Theodore leverages the information he has, playing one witness against another: the son finally confesses that the father, indeed, had been teaching him to "reproach the flesh."

64. Ep. Amm. 20 (Goehring, Letter of Ammon, text: 141, trans.: 171).

65. Ep. Amm. 26 (Goehring, Letter of Ammon, text: 148, trans.: 175-76). 
In both stories about Theodore and also in the earlier story about Pachomius and the foul-smelling visitors, angelic appearances allowed the leader of the community to challenge the doctrinal or practical errors of others without having had to have learned of these errors through other monks. ${ }^{66}$ These appearances remove the limit that avoidance of slander might impose: if Pachomius and Theodore are reporting what angels tell them, not only is that information likely true-indeed, in all the stories related here, the information turns out to be reliable-but it also is free from the stain of having been passed from one monk to another. The pattern of such stories, in which angels offer negative reports so monks do not have to, likely served a second purpose, demonstrating to later readers how to handle the discovery of heresy. They provided a cover story of sorts to would-be monastic informants by eliding the source of the damaging reports into a generic message from an "angel." Later leaders of monastic communities might learn from such stories how to protect the anonymity of their sources, whether by citing angelic visions as the source of their information or by playing on the ambiguity of the word ó $\gamma \gamma \varepsilon \lambda_{0} \varsigma$, "angel," which in Greek and Coptic also can mean simply "messenger." In turn, having read these stories, monks with information to report might hope their superiors would follow this pattern.

The prospect that stories like these can telegraph a model for dealing with heresy is further bolstered by the fact that two of them are marked by their involvement with the archetypical heresy that occupied Egyptian ascetic communities: the Origenist heresy. ${ }^{67}$ The story of Pachomius and the foul-smelling visitors is explicit about the cause of their odor: it is because these monks "read the works of Origen" that they reek. The second story of Theodore's angelic visions has him correct a brother who teaches "there is no resurrection of the flesh," one of the doctrines that characterized the position of those branded as "Origenists." It is also interesting that these stories deal with exposing "Origenists," because the main tenet of the position characterized in that way was that the divine cannot have a human form; there is no "likeness" of the divine that can be seen.

66. Angels sometimes take matters into their own hands. In the alphabetical collection, there is the story of a brother whose errors in thinking about the Eucharist are corrected by the appearance of an angel during the rite: AP Daniel 7 (PG 65:156C-160A). Cf. the anecdote in the Lausiac History about Marcus the ascetic, who receives his communion from the hand of an angel (H. Laus. 18 [ed. Butler, Lausiac History, 56, 3-10]); it is possible that this story obliquely affirms Marcus's orthodoxy regarding the Eucharist.

67. See Elizabeth Clark, The Origenist Controversy: The Cultural Construction of an Early Christian Debate (Princeton: Princeton University Press, 1992). 
Evagrius, most likely at the center of the movement to avoid picturing the divine, warned his readers against more than just imagining God. Rather, he urged them, "Hold no desire to see angels or powers or Christ with the senses, lest you go completely insane, taking a wolf to be the shepherd and worshipping your enemies, the demons." ${ }_{68}$ In what must be seen as an ironic twist, angels appear to Pachomius and Theodore in order to accuse exactly those people who would suggest that angels should have no appearance, namely probable "Origenists." These stories are doubly anti-heretical, their protagonists seeking out heretics by means of the very thing the heresy denies.

To extend the irony, we should consider the fact that the Origenist controversy appears to have started with the vision of an angel, according to one of the two ancient sources describing its beginnings. The Coptic Life of Aphou details the reception of a festal letter distributed by Theophilus, bishop of Alexandria, in which he denies that the divine has an image. ${ }^{69}$ Aphou, a monk who had been living alone in the desert, comes to gather with the other members of his community for the reading of Theophilus's festal letter. The Life of Aphou relates that

while [Aphou] was still living with the wild beasts he left for the proclamation of holy Easter. He heard a statement that did not accord with his understanding of the Holy Spirit. As a result, he was very upset at what he heard. Indeed, everyone who heard it was saddened and upset over it. But the angel of the Lord commanded blessed Aphou not to be indifferent to what was read, saying to him, "You have been appointed by the Lord to go to Alexandria to take issue with what was said." The wording of that proclamation went like this: in exalting the glory of God in the proclamation, it emphasized human weakness, and the person who had dictated it said that "this weakness is not the image of God," understanding "this weakness" to be we who bear the image, that is, we human beings. $(5-6)^{70}$

68. Evagrius, or. 115 (Sinkewicz, Evagrius of Pontus, 205-6). One might think this advice is a bit difficult to take, since the rewards of good behavior can include visions of angels. Consider the contrast Evagrius makes between the angry person and the patient person in Eight Thoughts. On the subject of anger, Evagrius finishes the section by summing up this way: "The irascible person sees disturbing nightmares, and an angry person imagines attacks of wild beasts. A patient person has visions of encounters with holy angels, and one free from resentment discourses on spiritual matters and receives in the night answers to mysteries"; 8Th. (Sinkewicz, Evagrius of Pontus, 81).

69. John Cassian, Conference 10.2 is the other source for this encounter.

70. Tim Vivian, trans., Four Desert Fathers: Pambo, Evagrius, Macarius of Egypt and Macarius of Alexandria (Crestwood, NY: St. Vladimir's Seminary Press, 2004), 183. 
As Aphou and his fellow ascetics listen to the letter of Theophilus, they have a disturbing experience: Theophilus asserts that humanity does not share in the image of God, a view that discomfits those who hear it. ${ }^{71}$ While the entire group is upset, only Aphou moves to take action, being emboldened by an angel. After his encounter with the angel, Aphou stands ready to challenge the text of the letter and prepared with the exact words to do so.

The angel gives Aphou the initiative to challenge the bishop, and that initiative must have been strong, for the gap between a monk from the wilds and the bishop of the largest city in Egypt was a power differential to be respected. Once Aphou has an audience with Theophilus, however, none of his weaknesses, be they social or spiritual, hinder the conversation. ${ }^{72}$ Instead, because of Aphou's confident speech, Theophilus agrees to change the wording of his letter and issues a correction at once, saying "I see that your appearance is that of a peasant, but on the other hand I can hear that your words are more elevated than the words of those who are wise" $(16-17) .{ }^{73}$ When Theophilus asks why he alone, of all those bothered by the phrase, was the only one to speak up, Aphou answers, "[for my part], I am confident that you will agree with me and will no longer oppose me." ${ }^{74}$ Let us remember that at the start of this narrative, Aphou is upset by the phrase in Theophilus's festal letter, but he appears unprepared to do anything about it. In fact, his lowly status militates against him challenging the bishop of the most important city in Egypt. Thus, the angel of the Lord instructs him specifically "not to be indifferent to what was read." However, in his response to Theophilus, Aphou does not tell the bishop about the visit from the angel. If we are to avoid charging Aphou with pride when he meets with Theophilus, why would the text omit the reason for his challenge?

71. Cassian describes Theophilus's letter as a "long refutation of the absurd heresy of the anthropomorphites" (Conference 10.2; Owen Chadwick, ed. and trans., Western Asceticism, Library of Christian Classics [Philadelphia: Westminster, 1958], 234).

72. The text of the Life of Aphou marks this difference in the ways it chooses to depict the monk. When Aphou joins the celebration of Easter, he leaves behind the wild beasts he lives with (5). As he prepares to go to Alexandria, Aphou puts on a "raggedy garment" (7). His appearance is so meager that he is ignored for three days after he arrives and the bishop's servants are afraid to present him at court (7). As if these clues weren't enough, Aphou identifies himself as a "poor man."

73. Vivian, Four Desert Fathers, 187.

74. I reproduce Vivian's translation above, but add "[for my part]" in order to point out the particularly telling nature of the construction here. By using a pronoun unnecessary to the Coptic, Aphou may be emphasizing that it is he, and no one else, that is confident. See the discussion of "personal independents" in Bentley Layton, $A$ 
It is possible to contextualize the omission by looking at Theophilus's own role in the Origenist controversy. This episode between Aphou and Theophilus was only the beginning of the controversy, and Theophilus changed his allegiance several times, his support wavering between monks who held the idea that the divine may be partially represented in human form and other monks who did not. ${ }^{75}$ Even though the Life of Aphou champions a monk who led Theophilus to allow that the divine may have a likeness among human beings, it still exhibits caution about having Aphou be inspired by the vision of an angel. Aphou's reluctance to report the source of his boldness suggests that even this text, extremely sympathetic to one who had such a vision, manifests a wariness about monks seeing angels.

Such ambivalence about angelic appearances among ascetics is not limited to the Life of Aphou. The idea that ascetics were "living the angelic life" led many to imagine that angels might be present in ascetic communities. We have seen that appearances of angels in these communities could accomplish constructive things: angels inspire good behavior and, when good behavior is lacking, repentance; angels by their presence steer ascetics to edifying topics of conversation; angelic appearances even resolve situations that seem to demand that monks engage in one vice-slander-to prevent another-heresy. However, other works of ascetic literature share the concern demonstrated by the Life of Aphou about visions of angels. In the next section, I will explore this concern, as well as the other less-thanhelpful effects of the equation of the ascetic life and the angelic one.

\section{TROUBLE IN THE CITY IN THE DESERT: ANGELIC EXPECTATIONS}

In the alphabetic collection of the Apophthegmata Patrum, Megethios laments the golden days of his community: "In the beginning, when we came together, we spoke of beneficial things, encouraging one another, and we became choirs upon choirs [of angels]; we ascended up to the heavens. But now when we come together, we gossip, one against the other, and thus go down [to hell]." ${ }^{76}$ The complaint is not a new one. ${ }^{77}$ However,

Coptic Grammar with Chrestomathy and Glossary: Sahidic Dialect, Porta Linguarum Orientalium 20 (Weisbaden: Harrassowitz, 2000), 65 (\$77).

75. See Clark, The Origenist Controversy, 43-84, esp. 44-60.

76. Megethios 4 (PG 65:300).

77. See the litany of religious laments for the splendor of the past in Annie Dillard, For the Time Being (New York: Knopf, 1999), 60-62. 
the specificity of Megethios's complaint can illumine: he contrasts the heady early moments in his community, a time when he was one of many angels, with the more recent, and all too human, behavior of his group. The difference between the ideal of the ascetic life and its realities was likely harsh enough, but it may have been exacerbated by the portrayal of ascetic communities as "choirs upon choirs" of angels. There is evidence that, particularly for those who had heard tell of ascetic endeavors and were led to join these "angels" in the desert, the expectations created by such lofty descriptions of the ascetic life needed to be tempered by the wisdom of more experienced community members.

As I explained in the last section, the analogy of the ascetic project with the "angelic life" allowed those in ascetic communities to imagine that angels might appear to them. The stories collected in the Apophthegmata Patrum treat most of these appearances as problematic, if not outright dangerous. In the Greek anonymous collection, one saying tells the story of a young monk who is apparently piqued that other ascetics have seen angels while he himself has not: "An old man was asked, 'How do some say, "We see visions of angels"?'- and he replied, 'Happy is he who always sees his sins." "'78 This more experienced monk reassures the one who asked by noting that the visions of angels claimed by others are unreal, or, at the very least, inconsequential. It is possible to detect an emphasis on humility in the "old man's" response; having angelic visions and talking about them is a distraction from the primary purpose, the struggle with one's own sin.

Rejecting distraction is a message that underlies a longer narrative, this one focusing on an ascetic who has had an angelic vision himself.

A brother lived in silence. Wishing to deceive him, the demons appeared to him looking like angels, and roused him for the synaxis and showed him a light. So he went an old man and said to him, "Abba, angels come with a light and rouse me for the synaxis." The old man said to him, "Do not listen to them, my child, for they are demons, but when they come to waken you say, 'I wake myself when I wish but I do not listen to you.'" 79

The more experienced monk responds very quickly, discerning the presence of demons, rather than angels, in an instant. This may be simply the skill of a wizened ascetic who knows the temptations that come in one's practice, but notice that the troubled brother "lives in silence," a phrase

78. N332 (ed. Nau, ROC 17 [1912]: 210). The translations for this and the following three stories are adaptations from Benedicta Ward, The Wisdom of the Desert Fathers (Kalamazoo, MI: Cistercian, 1986), 53, 29-30, and 50.

79. N224 (ed. Nau, ROC 17 [1912]: 359). 
suggesting he himself may be well-advanced in his ascetic career. Perhaps both monks, and by extension, those who read the story for edification, can safely assume that any visitation is a demonic visitation.

Two other vignettes which propose a method for responding to such visits reveal that the pervasiveness of pride and the exercise of humility are at stake for ascetics when they see angels. The Greek anonymous collection of the Apophthegmata Patrum recounts that the "old men used to say, 'Even if an angel should indeed appear to you, do not receive him but humiliate yourself, saying, 'I am not worthy to see an angel, living in sin." " 80 Psychologically astute, this piece of advice does not on the surface deny that an ascetic may see an angel, but simply instructs the ascetic to humble himself regardless. The counsel, however, suggests by its wording that the elders should recognize that a misguided ascetic affected by the grandiosity that inspires - or is inspired by-a vision of an angel may not be capable in the moment of realizing that the vision is false. Thus it grants "even if an angel should indeed appear to you. ..."

Consequently, an ascetic convinced of his special status because of his experience of an angelic vision does not need to confront his pride until after the vision ends and the demon has been revealed. Consider this story from the anonymous collection: "The devil appeared to a brother disguised as an angel of light and said to him, 'I am Gabriel and I have been sent to you.' The brother said to him, 'See if it is not someone else to whom you have been sent; as for me, I am not worthy of it'-and immediately the devil vanished." ${ }^{81}$ Here the approach advocated by "the old man" works in practice: even when the vision is of an important angel like Gabriel, affecting humility allows the brother who experiences the vision to dispel it with its temptations. The underlying problem, pride, is taken care of with an affirmation of humility.

These stories highlight the ascetic emphasis on humility, but they tell us that more than just virtue is in play when monks have angelic visions. We have seen many cases where the presence of angels lends an otherwise unavailable authority to an ascetic: the old man who discerns appropriate behavior from the presence of angels or pigs, Pachomius and Theodore finding heretics through angelic reconnaissance, and Aphou speaking up to the bishop of Alexandria once prompted by an angel. Because angels supervise the activities of monks and help determine community standards, it could be destabilizing to the community order for an inappropriate monk to receive angelic visions. It is perhaps for this reason that 
the ascetic literature collected as the Apophthegmata Patrum goes to such lengths to contain, rebut, and eventually reject visions of angels as detriments to individual ascetics and the community as a whole. ${ }^{82}$

This is all the more true when, rather than being convinced they are seeing angels, ascetics are convinced of being angels. Even though the trope that the ascetic life is a life "equal to the angels" pervades the texts I have examined in this essay, the idea that one may actually live as an angel finds little purchase in them. Indeed, the literature rejects any such pretense. One example, the story of John the Dwarf and his unruly expectations about the ascetic life, has drawn comment from many interpreters. ${ }^{83}$ Perhaps it is a favorite because it strikes the sardonic tone that so satisfies readers of the Apophthegmata Patrum. One day, John realizes that he is like an angel.

He said to his older brother: "I want to be free from care, as the angels are free from care, since they do not work, but are ceaselessly serving God.” And, taking off his garment, he went out into the desert. Having spent a week thus, he returned to his brother. He knocked at the door, and [the brother] recognized him before he opened the door, saying "Who are you?" He responded "It is I, John, your brother." And he answered, saying to him "John became an angel, and he is no longer among humans." And he called for his help, saying, "It's me!" And he did not open the door to him, but left him to afflict himself until the next morning. Later, having opened the door to him, he said "You are human, it is necessary to work again so you can eat." And he was repentant, saying "Forgive me." 84

Clearly, John has overestimated his abilities, and his thoughts of living "like an angel" have, literally, left him shut out of the community. Even after he returns from his "angelic" retreat, John the Dwarf is no less proud, considering that he wishes to be immediately recognized as a brother of the monk who remained in his cell. It takes time, not to mention some physical affliction, to instill in John the proper understanding of his status as an ascetic.

To sympathize with John the Dwarf for a moment, were these ideas about seeing angels and being angels so extraordinary, given how ascetics

82. I thank Mark Graham for raising this point with me.

83. Daniel Caner, Wandering, Begging Monks: Spiritual Authority and the Promotion of Monasticism, Transformation of the Classical Heritage 33 (Berkeley and Los Angeles: University of California Press), 43, for example.

84. John the Dwarf 2 (PG 65:204-5); cf. Ethiopic collection 14.52, about Silvanos. See also Caner's discussion of "free from care" (Wandering, Begging Monks, $33 \mathrm{n}$.

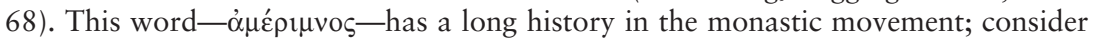
that it is the contemplation of Matt 6.34 ("Do not worry about tomorrow") that moves Antony to leave society (Ath., v. Anton. 3.1; SC 400:134). 
were represented by their admirers? That is, if the ascetic project was being experienced by lay Christians through literature and oration, media that often described the ascetic life as an angelic one, it cannot be beyond plausibility that lay Christians formed their expectations of ascetic practice and its rewards accordingly. Thus, when a Christian decided to join an ascetic community, part of the challenge may have been rooting out the unrealistic and even detrimental images created by being a spectator of ascetic lifestyles. ${ }^{85}$ In the Apophthegmata Patrum stories examined here, those who see angels or think themselves angels are less experienced; those who correct them are more experienced. It is in a new monk's negotiations of status and identity that conflict appears between the expectations of an observer and the realities of ascetic practice.

This same gap between expectation and reality prompts Shenoute, the leader of the White Monastery, to remind his monks that even though they are called "angels" by their admirers, this does not ensure a stable identity for them. He makes a distinction between righteous angels and sinning angels:

Are you not called, [my] congregation, by those who glorify you "heavenly Jerusalem" and the ones who dwell among you "angel"? You are always the same- "heavenly Jerusalem"- and the angels are those among you who fear God and observe his words. . . . If those holy ones among you resemble angels or are similar to them in their righteous deeds, then they also will be with the angels in the kingdom of God, in the way that the Scripture tells us. If, however, those who are defiled or who will defile themselves at some point among you resemble or are similar to the ancient sinning angels in their unclean deeds, then they will be with them in hell. ${ }^{86}$

Shenoute recalls for his monks those Christians, presumably outsiders, who think of them as a community which surpasses the world; they are a "heavenly Jerusalem," glorified as “angels." Angels, he threatens, come in

85. See Bentley Layton's discussion of the formation of monastic expectations in "Rules, Patterns, and the Exercise of Power," esp. 58-65.

86. This is an unpublished portion of a florilegium of Shenoutean texts; I thank Stephen Emmel for allowing me its use here. He has identified this particular fragment as a part of So Listen, from Canon 8 (XL297=FR-BN 1304 f.149): мн єүмоүте

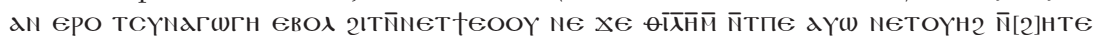

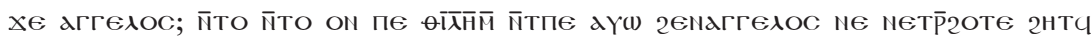

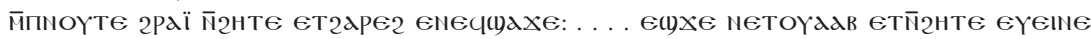

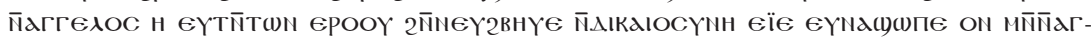

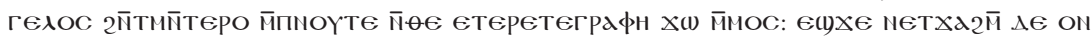

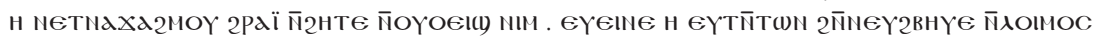

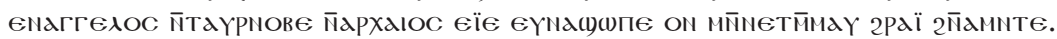


two species-heavenly and sinning — and his monks can align themselves with either group by their behavior.

Even the vigor behind such threats, though, did not blunt the disappointments created by the identification of the ascetic life with the angelic one. Consider the situation described in the Shenoute's work Why, O Lord, a part of Canon $4 .^{87}$ Some monks had recently left the monastery at Shenoute's request, and Shenoute wonders who, exactly, is responsible for the fact that the monks have, by leaving, broken their vows. Is it he, who enforced his will and forced the monks out of the community, or is it they, whose behavior was unacceptable and led to their expulsion? As Shenoute reconsiders his decision from several perspectives, he may sound like a hesitant young leader, but Why, O Lord was written after Shenoute had been at the head of the monastery for some time and thus reveals the regret of a seasoned leader after a traumatic event in his community. ${ }^{88}$

As he reviews the details of his decision to eject the offending monks, Shenoute repines against the distance between the perceptions of outsiders and the reality of the constant work he has to do to keep the monastery going:

Many times .... we spend the entire day speaking and convicting, petitioning, comforting, blessing, cursing, struggling, saying words of enmity, reciting words of peace, being holy and being civilized, being gentle in patience, loving anger, being small of heart in disturbance and more anger, weeping with tears, laughing with the comfort and fear of the Lord, knowing that we are condemned by [our] laughing because the thing that allows us to laugh "turns to grief," as it is written [alluding to James 4.9], because our sins grow "we are restless," as it is written [2 Cor 6.10?], and yet "we rejoice in the Lord," according to the Scriptures. We endure and we dwell and we gather together, saying such words as "Where are our friends on the outside, who come to us and call us 'angel'?" They see all of our bad deeds with our falsehood and our evil thoughts and they see us acting indecently in enmity with one another on account of our pride and our ignorance. ${ }^{89}$

87. What remains of Canon 4 is, as much of Shenoute's work, a composite of many different manuscript pieces. For a complete details about the Canon and its representation in the manuscripts, see Stephen Emmel's discussion in Shenoute's Literary Corpus, 2 vols. (Leuven: Peeters, 2004), 1:155-63 and 2:573-75, along with the table on 2:719-26.

88. Shenoute's Literary Corpus, 2:573-74. Emmel here is refuting the assertion of the editor of this part of Canon 4 for the CSCO series, Johannes Leipoldt, who had suggested that it may have been written shortly after Shenoute's taking of power.

89. Canon 4, Why, O Lord (ed. Leipoldt, De eis qui e monasterio discesserunt, CSCO 42:116-51), cited at 148-49; the operative part of the citation reads in Cop-

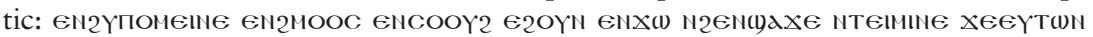
нен(gвєер єтгівол етннү нан етмоүте ерон хедггелос; 
Given the machinations that Shenoute found necessary to lead his monastery-the constant management of emotions and reactions by cajoling, pleading, comforting, scolding - the fact that those outside the monastery could refer to him and his monks as "angels" must have seemed ironic to him, even bitterly so. ${ }^{90}$ For all his efforts, the "bad deeds" and "evil thoughts" of the community were exhibited publicly; "pride" and "ignorance" were in evidence among his monks. While being called an angel may have been meant in admiration, to Shenoute, such a term could only point out his failings as a leader.

Even in antiquity, those Christians who rejected sexuality and family to live in the monasteries and "deserts" of Egypt were viewed as superstars, their way of life being so perfect as to be "equal to the angels." It is clear that Egyptian ascetics knew others praised them by making a connection between their practices and the "angelic life." This connection entered into the ways that ascetics thought both of themselves and of their project. Such a discourse worked constructively-establishing boundaries between the community and the world, affirming certain behaviors while allowing for others to be avoided-but it also created problems of authority and arrogance among ascetics. When we read texts, be they ancient or modern, that compare ascetics to angels, we must remember Shenoute's warning. The idea that Christian ascetics were living "the angelic life" carries varied and even opposite effects, some worthy and helpful, like the righteous angels in the kingdom of God, and others difficult and troubling, like the defiled angels who reside in hell.

Ellen Muehlberger is an Assistant Professor of Religious Studies at DePauw University

90. Shenoute's litany serves another purpose, namely to project Shenoute as a "suffering servant," one who must work constantly to overcome the difficulties created by those in his community who err. See Rebecca Krawiec's discussion of this trope in Shenoute's writing (Shenoute and the Women of the White Monastery: Egyptian Monasticism in Late Antiquity [New York: Oxford University Press, 2002], 69-71). 